\title{
Can the decline in happiness in Europe be attributed to the COVID-19 pandemic and its interaction with the budget deficit?
}

Gilbert Noula Armand

University of Dschang: Universite de Dschang

Désiré Avom

University of Yaounde II: Universite de Yaounde II

Orfé Chouafi Nguekam ( $\sim$ orfchouafi@yahoo.fr)

University of Dschang: Universite de Dschang https://orcid.org/0000-0001-6825-3088

Salomon Leroy Ghamsi Deffo

University of Dschang: Universite de Dschang

Martial Aimé Kenfack

University of Dschang: Universite de Dschang

Ali Salim NGNEMADOM AHMED

University of Dschang: Universite de Dschang

\section{Research Article}

Keywords: COVID-19 pandemic, happiness, fiscal deficit, Europe

Posted Date: February 16th, 2022

DOI: https://doi.org/10.21203/rs.3.rs-1318663/v1

License: (1) This work is licensed under a Creative Commons Attribution 4.0 International License.

Read Full License 
Title: Can the decline in happiness in Europe be attributed to the COVID-19 pandemic and its interaction with the budget deficit?

\begin{abstract}
The outbreak of the COVID-19 pandemic has caused a great slump in the world. There has been an alarming increase in mortality rate, number of infections, and deterioration of macroeconomic indicators such as GDP, which have worsened the happiness and well-being of the population, despite the multi-faceted restraint and supports measures implemented by several governments to curb the spread of the virus. Using sample of 31 European countries as a dataset, this paper analyzes the effect of the worsening COVID-19 budget deficit on people's happiness in the year 2020. The main idea is to determine, independently of a country's characteristics, the duration of the pandemic or the containment regulations; whether the effect of the pandemic on happiness is increased by the worsening of the budget deficit. The Generalized Least Squares (GLS) and 2SLS estimation show that death tolls and infected cases of COVID-19 are key determinants that significantly worsen individuals' happiness. In addition, its interaction with fiscal deficit further decreases people's life satisfaction, since the budgetary situation of these countries was already unsustainable long before the pandemic. Hence, there is urgency for States to provide for a community solidarity fund for the resources necessary for crisis management in their budget line.
\end{abstract}

\title{
Keywords: COVID-19 pandemic, happiness, fiscal deficit, Europe
}

\section{JEL Code: I12, I31, H62}

\section{Introduction}

The COVID-19 pandemic has caused several dysfunctions in the world's economies resulting to enormous consequences such as disease, economic instability, uncertainty, stress and high mortality rate. In such a context, the happiness of individuals has been weakened. Furthermore, the European Central Bank (2020) points out that this pandemic has weakened fiscal positions, as automatic stabilizers and discretionary measures result in higher deficits in European Union's countries. Research on the adverse effects of the COVID-19 pandemic has shown a decline in individuals emotion and happiness during this period (Greyling et al. 2020; Sibley et al. 2020; Brodeur et al. 2020). Blustein et al. (2019) show that since its inception, the COVID-19 pandemic has led to numerous job losses and the emergence of financial debts related to isolation, depression, identity disruption, cognitive dissonance, and, in turn, the degradation of people's well-being and happiness.

Shortly after the COVID-19 outbreak, government debt ratios followed an unsustainable path in the already highly indebted euro countries as a result of the more severe and prolonged than expected contraction in economic activity, combined with higher sovereign financing costs. In the first quarter of the year 2020, GDP contracted by more than 5\% in France, Spain, and Italy (Jena et al. 2021). By April 4, 2021, unemployment insurance claims in the United States had increased 30-fold, to more than six million cases in a single week (Larson and Sinclair 2021). Yet, in 2020, the World Bank has estimated the overall contraction of economic activity to be around 10\% in the European Union, $9 \%$ in India and almost $8 \%$ in the United States. For Kapoor and Buiter (2020), the disadvantages of COVID19 can be seen in the decline in corporate profits, the decrease in consumption and the increase in unemployment, leading to a decline in revenues from corporate income tax, goods and services tax and personal income tax respectively. As a result, the deterioration in the happiness of most European countries. In the third quarter of 2020, while COVID-19 control measures were relaxed by member states compared to the second quarter of 2020, the 
seasonally adjusted government deficit-to-GDP ratio stood at $-5.8 \%$ in the euro area. Seasonally adjusted total government revenue in the euro area was $46.2 \%$ of GDP, down from $47.7 \%$ of GDP in the second quarter of 2020. Total government spending in the euro area amounted to $52.1 \%$ of GDP, down significantly from $59.6 \%$ of GDP in the previous quarter. Previous studies show that its negative effects on happiness are disproportionately perceived by workers at the lower end of the income scale, who often work in less decent occupations and are less likely to be assigned to desk jobs (Bhattacharya et al. 2021; Chopra et al., 2020; Guimaraes, 2021; Berger et al., 2020; Brotherhood et al., 2020; Baril-Tremblay et al. 2021; Bandyopadhyay et al. 2021; Bouveret and Mandel, 2021). In an effort to improve individual happiness, Albis and Augeraud-Véron (2021); Bosi et al. (2021); Caulkins et al. (2021) have conducted recent studies focusing on the prevention and eradication of this pandemic. The work of Douglas et al. (2020); Torjesen (2020); Roca, Vicens and Gili (2020) demonstrates that the key determinants of individual well-being such as health, job satisfaction, relationships, income, employment and non-criminality are most declining in Europe, calling for the availability of mental health support services in anticipation of a potentially large spike in demand. Di Tella et al. (2001) in past studies have shown that individuals living in areas with higher inflation or unemployment have low levels of happiness. Krekel et al. (2016), Luechinger (2009) stipulate that access to green spaces with less pollution stimulates happiness.

Using Behavioral Risk Factor Surveillance System (BRFSS) data from 2005-2008, Oswald and $\mathrm{Wu}$ (2010) find that U.S. states with more attractive characteristics (in terms of weather, environment, crime, education, real income, etc.) also have higher life satisfactory scores. Since income is one of the determinants of happiness, the IMF estimated that overall advancement decreased by $-3 \%$ in 2020 , which is the reason for the lower satisfaction observed in several countries around the world. According to the OECD (2020), GDP contracted by $3.5 \%$ in the European Union during the first quarter of 2020 and unemployment rose from $5.4 \%$ before to $9.2 \%$ during the epidemic. According to Johns Hopkins University (2020), the global health pandemic, caused by the Coronavirus (COVID-19) outbreak, has killed more than 460,000 people worldwide (as of June 2020) and more than 8.9 million people worldwide have tested positive for the virus. In addition, studies by Greyling et al. (2020); Brodeur et al. (2020) specify that the pandemic to overlap on an increase in the degree of boredom, loneliness, worry and sadness during the pandemic.

Many studies have examined the effects of the pandemic on feelings, mood and health status - in particular, mental health - among both Italians (Marazziti et al. 2020; Maugeri et al. 2020; Rossi et al. 2020; Sani et al. 2020; Gualano et al. 2020) and Japanese (Yamamoto et al. 2020; Qian and Yahara, 2020; Ueda et al. 2020). However, some of these studies have focused on target populations, such as the elderly and the young or unemployed (Orgilés et al. 2020; Shigemura et al. 2020). In addition, special attention is also paid to people involved in COVID-19 care activities such as medical workers, who may suffer from high emotional distress and stigma effects (Shigemura and Kurosawa, 2020; Asaoka et al. 2020; Torricelli et al. 2020); pregnant women and newborns (Haruna and Nishi, 2020), patients with specific pathologies (Capuano et al., 2020). All these studies aim to assess the impact of the pandemic on individual and collective well-being and suggest priorities for intervention.

All economic forecasts agree on the heavy consequences that the pandemic will have, not only in the short term, on global GDP, consumption, employment and stock market values, while specifying that the impact of its distribution over time is still rather uncertain (Chudik et al. 2020; Chudik et al. 2020; Baldwin and Weder di Mauro, 2020; Lima et al. 2020). There are no studies to our knowledge that have shown how the negative influence of COVID-19 on happiness has been reinforced by the worsening budget deficit in Europe. The rest of this article is organized as follows: Section 2 is a brief presentation of the existing 
literature on the subject. Section 3 presents the estimation approach and descriptive statistics; Section 4, the results of the regression analysis and Section 5 concludes.

\section{Literature review}

Recent empirical literature, although less abundant, provides a number of indicators that influence, for some, the well-being of individuals and, for others, happiness.

Indeed, Brodeur et al (2020) and Hamermesh (2020) use Google Trends to study the effect of government restrictions on well-being, mental health and life satisfaction. They find a negative effect on well-being and mental health as measured by increases in sadness, worry and loneliness. Hamermesh (2020), in running simulations, holds that single people were less satisfied with life than married people during the COVID-19 period. Greyling et al. (2020) used the social media platform Twitter and gross national income to study the determinants of happiness before and after applying a weighting factor in the case of South Africa. They found that restrictions on mobility, the closure of places to sell and consume alcohol, and schools negatively affected happiness. However, they conclude that there is a mixed relationship between regulations to control the spread of the virus and people's happiness. Furthermore, they corroborated the findings of Jones and Salathe (2019) that the threat of COVID-19 dissipates over time and does not appear to impact happiness as such. Rossouw et al (2020), using the New Zealand National Happiness Index, found through the use of a Markov switching model that the factors determining happiness are related to international travel, employment, and mobility. These factors have been declining since the beginning of the COVID-19 pandemic in New Zealand.

Using survey data collected at two time points (December 2019 and April 2020) for 1003 individuals, Sifbley. et al. (2020) found that containment regulations slightly increased feelings of community and trust in institutions. They also warned of long-term mental health issues as levels of anxiety and depression increased after the government restrictions. After collecting survey data, Briscese et al. (2020) study how individuals intentions to comply with the self-identification policy were perceived. From this study, they derive that respondents were more likely to reduce rather than increase their self-isolatory efforts if the measures set for extension were longer than expected. Fang et al. (2020) quantified the causal impact of human mobility restrictions, particularly the closure of access to Wuhan City, to limit the delay in the spread of COVID-19. Their analyses showed that the containment of Wuhan city had significantly contributed to the reduction of the total number of infected COVID-19 cases outside Wuhan, even with the social distancing measures imposed later by other cities.

The work of Bryson et al. (2016) and Piekalkiewicz (2017) show that happiness can act as a determinant of economic outcomes: increases in productivity predict increases in an individual's future income and affects labor market performance. On the other hand, recent studies by Algan et al. (2019) show that GDP cannot be an ideal indicator for measuring individuals' happiness because it does not take into account non-market social interactions, such as friendship, family, moral values, and the cost of living. In work conducted by LeighHunt et al. (2017), Verne (2009), Clark \& Oswald (1994), unemployment, social isolation, and lack of freedom, are considered risk factors that can deteriorate mental health and happiness.

Examination of changes in happiness in Great Britain during the first wave of the pandemic in spring 2020 is the subject of studies by Foa et al. (2020) where they show that the imposition of containment measures affects well-being positively through increased autonomy of remote workers and adoption of government support programs. The significant change in household economic sentiment in 27 EU countries as a result of the COVID-19 epidemic and the resulting containment restrictions is studied by Van der Wielen and Barrios 
(ming). This research, like the previous ones, relies on a panel dataset from Google Trends, covering the business cycle, the labor market, and consumption. As a result, the study finds a substantial deterioration in happiness in all dimensions studied in the months following the outbreak of the pandemic, but neglects the state budget deficit.

\section{Data and methodology}

\subsection{Data}

We used data from a group of 31 European countries for the year 2020, the year in which most of the countries in our sample not only recorded the first cases of COVID-19, but also the year in which the countries recorded the highest death tolls due to this virus. The data used come from various sources such as Euro_stat (2021), World Development Indicators (WDI, 2021), Global Health Observatory (WHO, 2021), Happiness Data Base (2021) and World Economic Forum (2021). Data on the spread of COVID-19 include the total number of confirmed cases and the total death tolls. The list of countries of our sample is content in table 1 which is in appendix.

Table 2 presents the descriptive statistics for the variables mobilized in our entire sample. We refer to Duration as the variable that accounts for differences in the timing of the disease outbreak, i.e., the number of days from the first case of COVID-19 to the observed date.

Table 2: Descriptive statistics of variables

\begin{tabular}{llllll}
\hline Variables & Obs. & Mean & Std.dev & Min & Max \\
\hline Hapiness index & 31 & 6.7151 & 0.6090 & 5.598 & 7.889 \\
Budget Deficit (\% of GDP) & 31 & -6.7455 & 2.7309 & -13.43 & -1.1 \\
Number of death (in thousands) & 31 & 458.2072 & 609.61 & 0.387 & 2376.852 \\
Number of case (in thousands) & 31 & 118.7209 & 418.5328 & 0 & 1876.819 \\
GDP growth (in \%) & 31 & -5.0710 & 3.1399 & -10.8 & 3.4 \\
Duration (in days) & 31 & 21.682 & 9.423 & 2.651 & 78.980 \\
Travel and tourism competitiveness & 31 & 4.5677 & 0.4269 & 4 & 5.4 \\
index & & & & & \\
Inflation & 31 & 0.9156 & 1.2330 & -1.2480 & 3.3745 \\
Capital Stock (in \% of GDP) & 31 & 6149.034 & 15951.35 & 23.4127 & 88753.07 \\
\hline Source: Authos
\end{tabular}

Source: Authors calculations

Figures 1 and 2 below show, respectively, that during 2019-2020, the majority of European countries experienced a slowdown in Happiness and a worsening of their fiscal situation in almost all countries. 


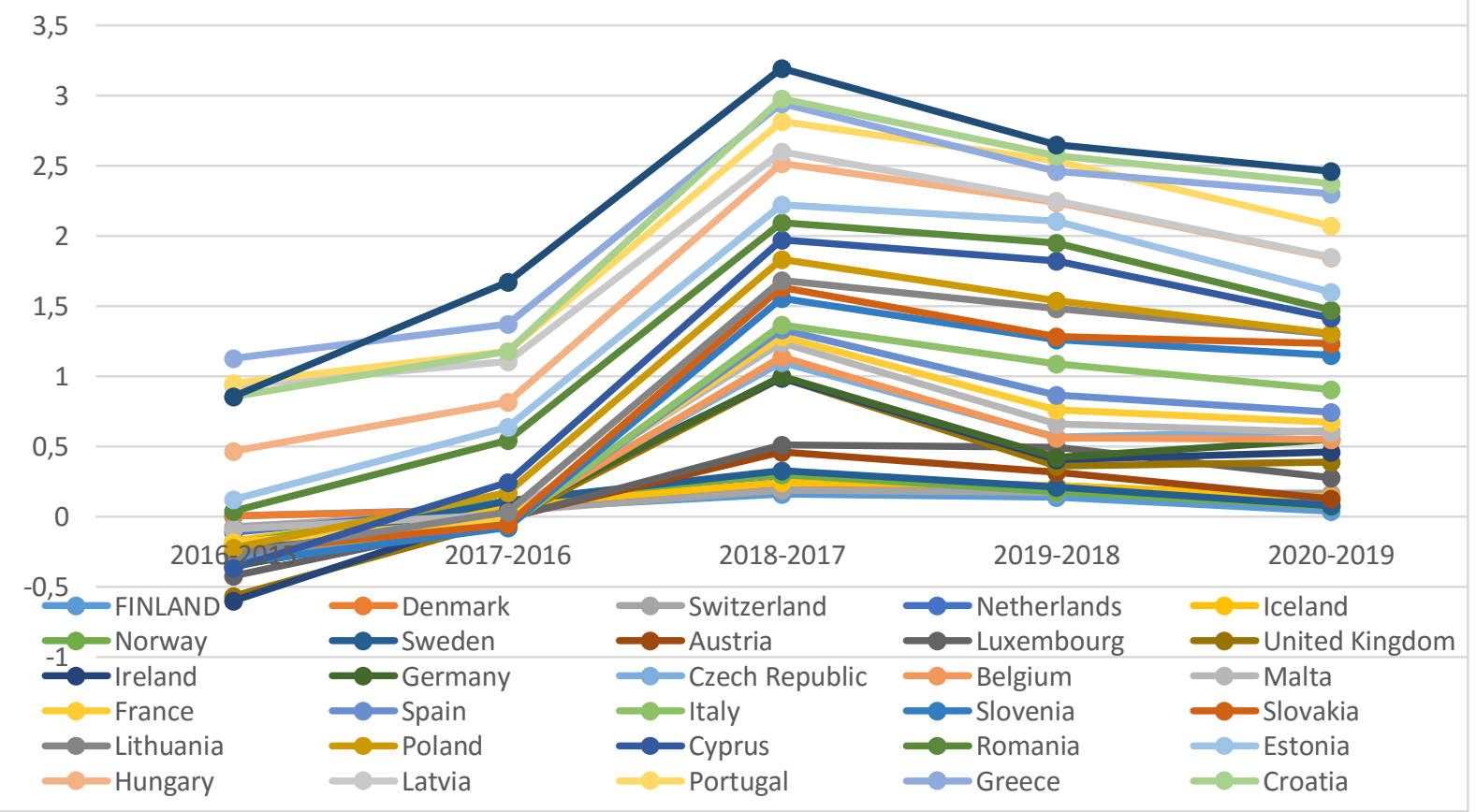

Fig. 1: Evolution of the growth of happiness in absolute value in European countries Source: Authors calculations

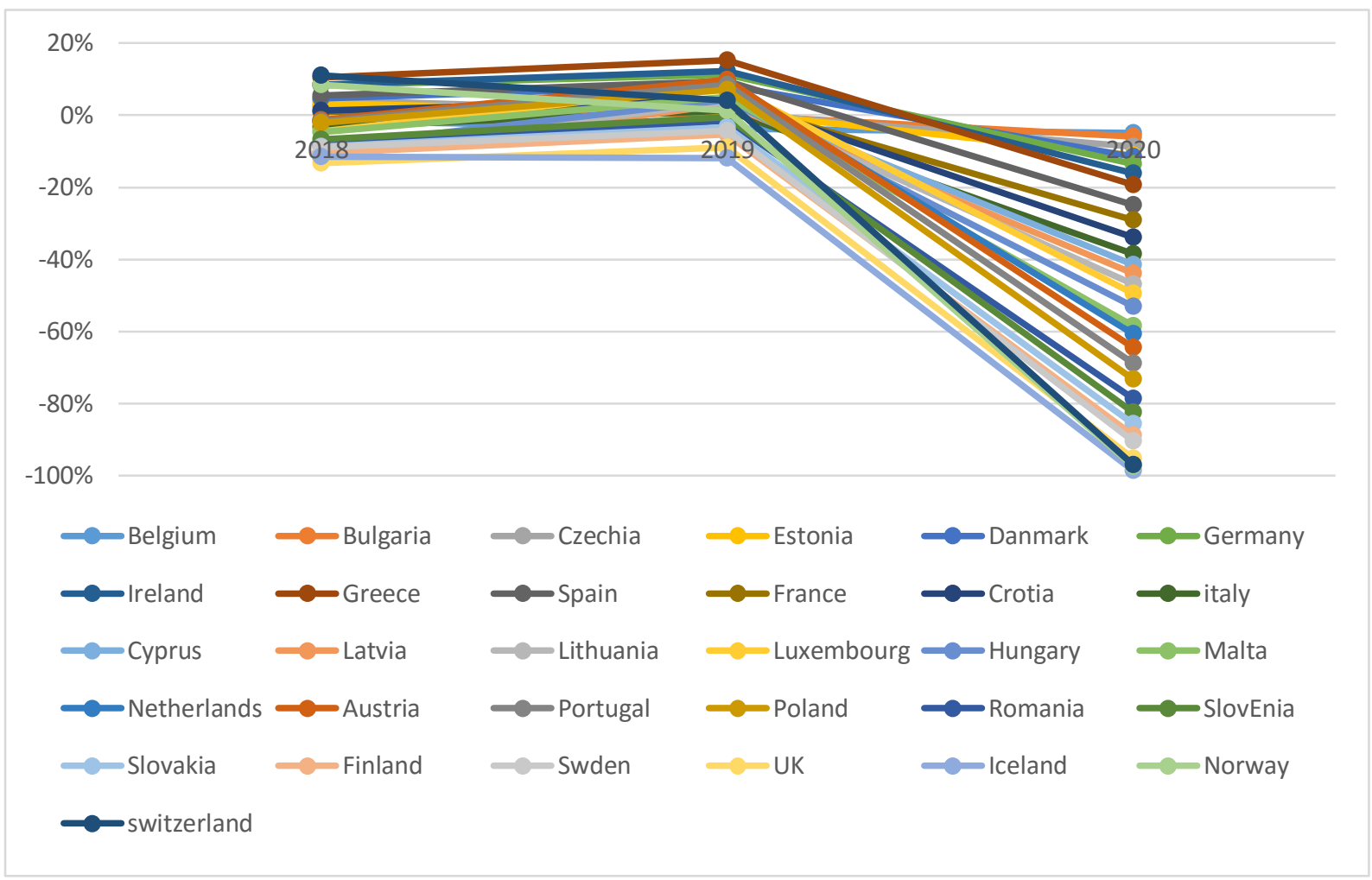

Fig.2. evolution of the budget deficit of European countries

Source: Authors calculations 
As show in figure 3 below, the United Kingdom reported the highest absolute number (over 46 000), followed by Italy, France and Spain with each reporting more than 35000 deaths. Adjusting for population size, Belgium reported over 1000 COVID-19 deaths per million people; followed by Spain, the United Kingdom, Italy, Sweden and France, all with over 500 COVID-19 reported deaths per million people. Reported rates up to the end of October 2020 were lowest in some Nordic countries (Finland, Iceland, and Norway), the Baltic countries (Estonia, Latvia, and Lithuania), the Slovak Republic, Greece, and Cyprus (Figure 4).

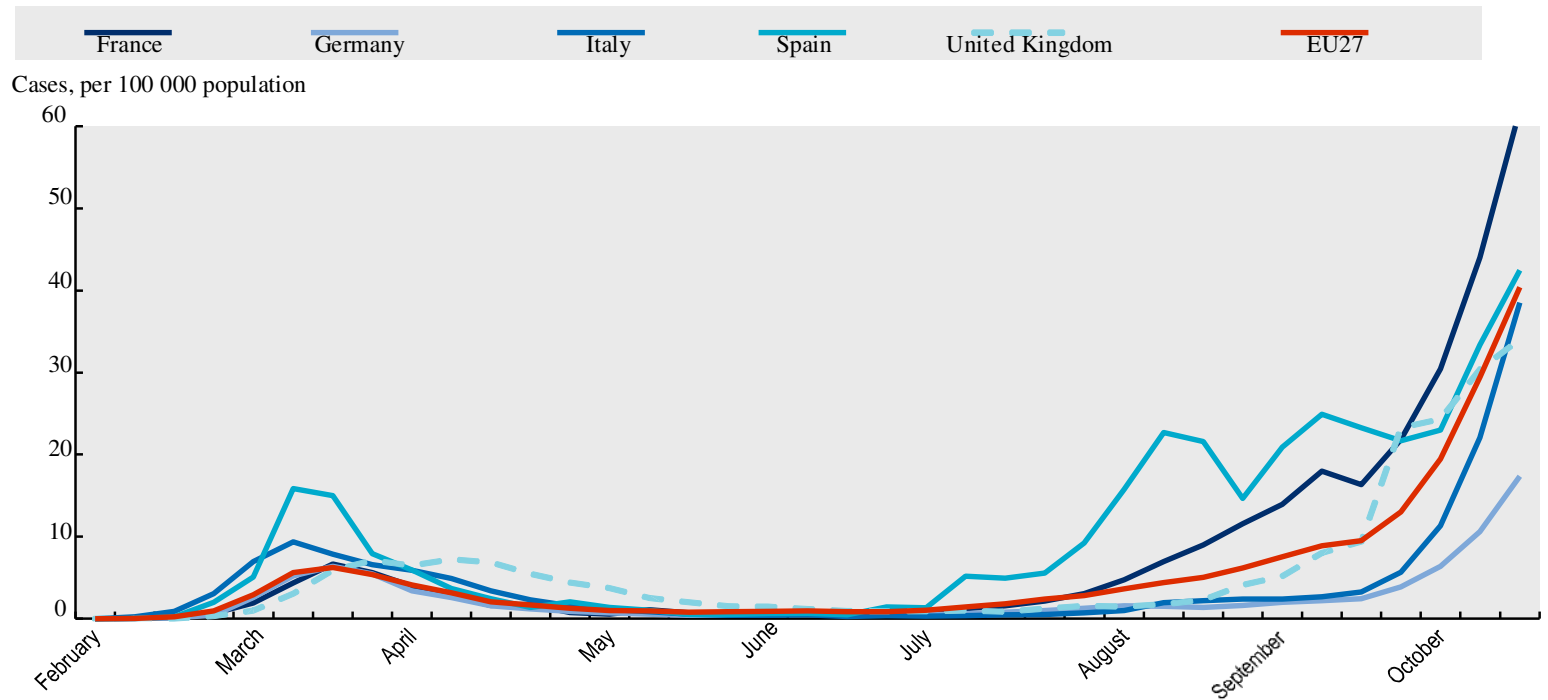

Fig. 3. Evolution in reported COVID-19 cases, EU average and most populated European countries, February to end of October 2020

Note: The EU average is weighted.

Source: European Centre for Disease Prevention and Control (ECDC).

StatLink $\rightleftharpoons$ https://stat.link/rphivu

\begin{tabular}{|c|c|c|c|c|c|}
\hline Croatia & Czech & Republic Poland & Romania & Slovak Republic & Slovenia \\
\hline
\end{tabular}

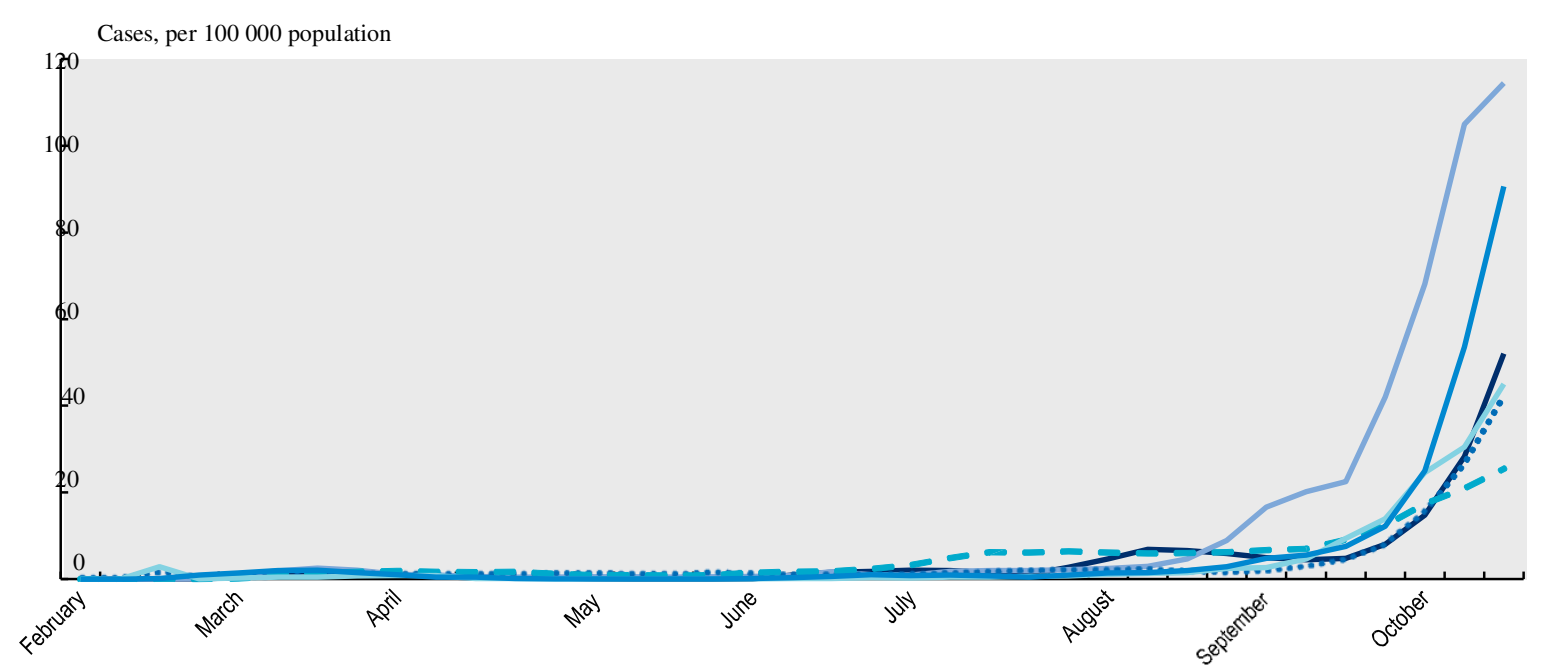

Fig 4. Evolution in reported COVID-19 cases, selected Central and Eastern European countries, February to end of October 2020

Source: European Centre for Disease Prevention and Control (ECDC).

StatLink

https://stat.link/Orsxlt 


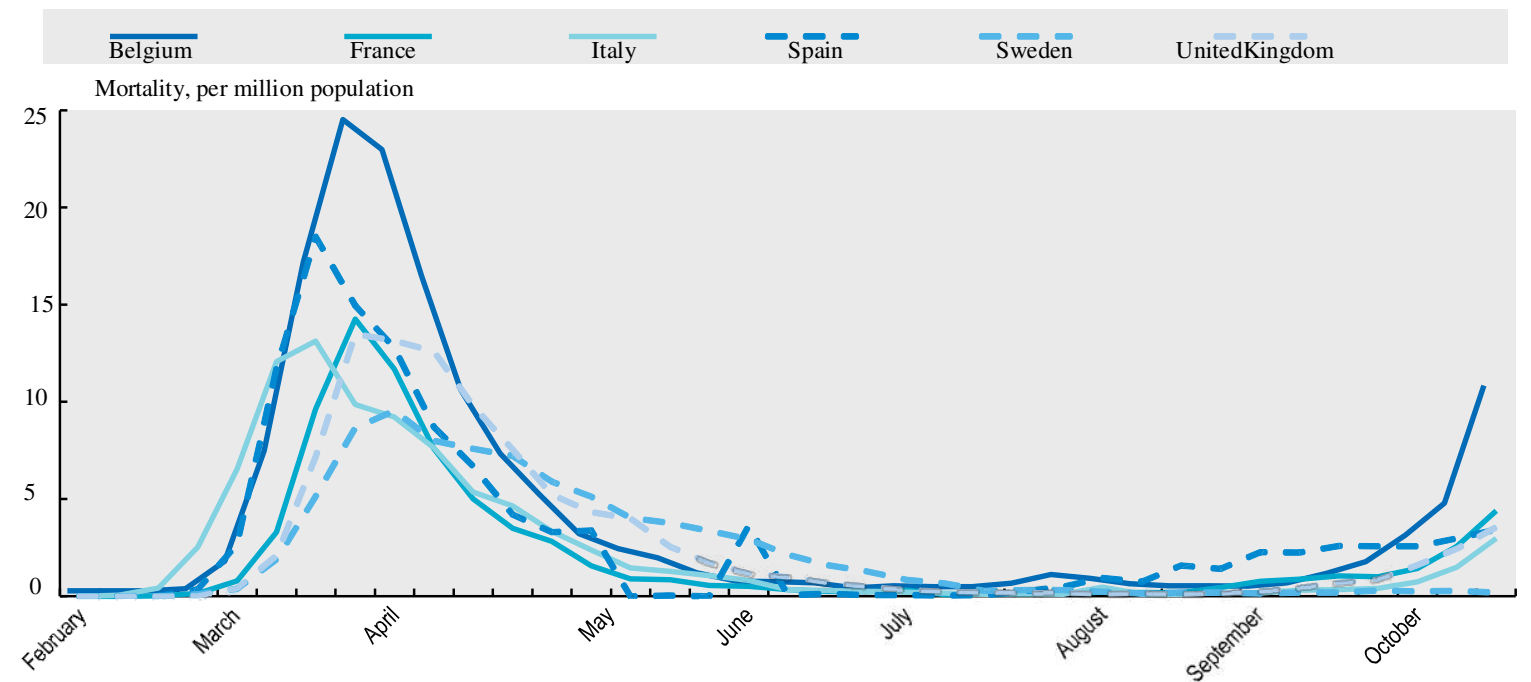

Fig.5. Evolution in reported COVID-19 mortality rates in some of the most adversely affected countries in Europe, February to end of October 2020

Source: European Centre for Disease Prevention and Control (ECDC).

StatLink $\geq$ https://stat.link/uiybal

In figure 5 above, during the first wave, daily COVID-19 deaths peaked in early April for these countries, before gradually declining from May through July, though from late August deaths have started to increase again.

\subsection{Methodology}

Based on the recent work of Nguimkeu and Tadadjeu (2020), this paper employs a linear baseline model to assess the effect of COVID-19 on happiness in Europe through interaction with the budget deficit. The empirical model is as follows:

$H_{a p}=a_{0}+a_{1} D C_{i}+a_{2} B D_{i}+a_{3}\left(D C_{i} * B D_{i}\right)+\sum_{i=4}^{8} a_{i} Z_{i}+\mu_{i}$

In this formulation, Hap is the dependent variable measuring happiness, i.e. the subjective enjoyment of life as a whole. It is taken from the Happiness data base (2021). The relevance of this indicator lies in its ability to measure, in real time, the feelings of citizens of countries during different economic, social and political events (Rossouw and Greyling, 2020). $Z$ is a vector of control variables.

The error term $\mu$ includes both the measurement error component and the initial error expected in the regression. The final empirical model is specified as follows:

$$
\text { Hap }_{i}=a_{0}+a_{1} D C_{i}+a_{2} B D_{i}+a_{3}\left(D C_{i} * B D_{i}\right)+a_{4} G D P G+a_{5} \text { Tour }_{i}+a_{6} \text { Infl }_{i}+a_{7} C S+a_{8} t_{i}+\mu_{i}
$$

In this specification, we have:

- $B D$ is the budget deficit variable measuring the difference between government revenues and expenditures in a year. An increase in the level of expenditures related to revenues during the COVID-19 period limits the state's ability to allocate resources to 
the vulnerable. Thus, a high level of deficit worsens happiness. It is taken from Euro_stat (2021);

- $\quad D C$ measures the number of deaths following COVID-19. Individuals' happiness is lowest when they lose a loved one. This variable comes from WHO (2021). The expected sign is negative.

- $\quad D C^{*} B D$, the interaction variable between the number of deaths and the budget balance. It measures how the worsening of the budget deficit during the COVID-19 period limits states' ability to take care of themselves and reinforces the pejorative effect of Covid19 on individuals' happiness. The expected sign is negative.

- $G D P G$ is the GDP growth rate. It comes from the data base of the World Bank (WDI, 2021). It is a macroeconomic indicator that predicts the evolution and purchasing power of individuals in an economy. When it is decreasing, it means that people do not have enough income to satisfy themselves. The expected sign is positive;

- CS measures the Capital Stock $(C S)$. It is the cumulative value of previous investments minus the cumulative consumption of fixed capital. This indicator makes it possible to assess the financial value of the gross capital stock. The capital stock devoted to net investment by economic agents during the COVID-19 period is decisive in determining their life satisfaction. However, not all individuals derive satisfaction from investment. The expected sign is ambiguous. It is taken from Euro_stat (2021);

- Infl measures the rate of inflation. Since the outbreak of the COVID-19 pandemic, states have progressively adopted restrictive policies concerning the closure of borders against the movement of people and goods. Thus, the purchasing power of Europeans has declined drastically due to increase in unemployment rate, compromising their satisfaction. This variable comes from the WDI (2021) and the expected sign is negative;

- Tour measures the intensity of tourism activity. In fact, this variable measures the competitiveness of tourism, the freedom to travel, as well as the set of factors and policies that allow the sustainable development of the travel and tourism sectors. This variable is derived from the World Economic Forum (2021) and the expected sign is positive;

- $\quad t$ The duration of the epidemic in country i (i.e., the number of days since the first confirmed case was reported in country i). 
La méthode des MCO est plus appropriée pour faire des régressions des modèles en coupe transversale, or, l'usage de cette méthode nécessite le respect des hypothèses relatif au terme d'erreur $\mu_{\mathrm{i}}$

\section{Results and discussions}

\subsection{Preliminary test results}

Table 3 below shows that there is intra-individual autocorrelation and that the model suffers from a possible endogeneity problem. The resolution of this problem requires the use of the instrumental variables method.

Tableau 3: Summaries of preliminary tests

\begin{tabular}{|c|c|c|c|c|}
\hline Type of test & Nul hypothesis & P-value & Decision & Consequences \\
\hline $\begin{array}{l}\text { Heteroscedasticity of } \\
\text { Breusch-Pagan test }\end{array}$ & Homoscedasticity & 0.0610 & accepted & $\begin{array}{l}\text { Heteroscedasticity } \\
\text { is absent }\end{array}$ \\
\hline $\begin{array}{l}\text { Ramsey-Reset test of } \\
\text { omitted variable }\end{array}$ & $\begin{array}{l}\text { Model doesn't have } \\
\text { efficient explanatory } \\
\text { variable omitted }\end{array}$ & 0.2150 & accepted & $\begin{array}{l}\text { Model is well } \\
\text { specified }\end{array}$ \\
\hline $\begin{array}{ll}\text { Variance } & \text { Inflation } \\
\text { Factor test } & \end{array}$ & $\begin{array}{l}\text { VIF must be greater than } \\
0.1\end{array}$ & 0.85 & accepted & $\begin{array}{l}\text { Multicollinearity is } \\
\text { absent }\end{array}$ \\
\hline $\begin{array}{l}\text { Intra-individual } \\
\text { autocorrelation test of } \\
\text { Wooldridge }\end{array}$ & $\begin{array}{l}\text { Autocorrelation of residual } \\
\text { is absent }\end{array}$ & 0.0000 & Rejected & $\begin{array}{l}\text { The autocorrelation } \\
\text { structure is AR(1) } \\
\text { and we must use } \\
\text { GLS method with } \\
\text { error correction }\end{array}$ \\
\hline $\begin{array}{l}\text { Residual normality test } \\
\text { of Skewness/Kurtosis }\end{array}$ & $\begin{array}{l}\text { Residual are normally } \\
\text { distributed }\end{array}$ & 0.0754 & accepted & $\begin{array}{l}\text { Residual are } \\
\text { normally } \\
\text { distributed }\end{array}$ \\
\hline $\begin{array}{l}\text { Endogeneity test } \\
\text { Durbin-Wu-Hausman }\end{array}$ & $\begin{array}{l}\text { Exogeneity of the variable } \\
\text { budget deficit }\end{array}$ & $\begin{array}{l}\mathrm{BD}=0.4 \\
327\end{array}$ & Rejected & $\begin{array}{l}\text { Endogeneity of the } \\
\text { variable budget } \\
\text { deficit }\end{array}$ \\
\hline Hansen/ Sargan test & $\begin{array}{l}\text { Budget deficit is not the } \\
\text { valid instrument if the p- } \\
\text { value is less than } 0.1\end{array}$ & 0.896 & Rejected & $\begin{array}{l}\text { This instrument is } \\
\text { valid }\end{array}$ \\
\hline
\end{tabular}

The above empirical model is a cross-sectional model. The statistical units are observed on the year 2020 from a group of 31 European countries. Indeed, the European continent is the one that suffered the most disastrous effect of the COVID-19 pandemic in 2020. In order to highlight the effect of the covid-19 pandemic on the happiness of Europeans, the study opted for the GLS method. The advantage of this method is that it automatically corrects for autocorrelation of residuals and heteroscedasticity.

\subsection{Results discussions}

Table 4, column (1) below represents the base model estimate (equation 2) and column (2) represents the robustness of the estimate. The interaction between the budget deficit and the death tolls positively affect happiness in Europe. This shows that the negative impact of the loss of closing a relative or neighbor due to COVID-19 on happiness is not isolated, but, further reduced by the deterioration of the budgetary situation. So, Europe countries increase 
their deficit in order to intervene in favor of the population affected by the pandemic. In fact, $1 \%$ increase in the interaction variable improve by $0,018 \%$ the level of happiness. Yet, we note that the duration of the pandemic throughout the 2020 period has had disastrous consequences for the countries of Europe, all other things being equal. No one can overlook the efforts made so far by governments and Non-Governmental Organizations (NGOs) to address this problem. This is the reason why the longer the pandemic lasts, the more the death tolls or infected persons might decrease in Europe, unlike in Sub-Saharan Africa.

Our most significant results are those related to touristic activity, the number of deaths or persons infected, and its interaction with the budget deficit. The results show that the evolution of mortality rate intends as an important demographic indicator to capture the degree of satisfaction with life of individuals who have lost their loved one, negatively and significantly affects the happiness of populations. Specifically, a $1 \%$ increase in death tolls is associated with a decrease of about $0.54 \%$ in the life satisfaction (happiness) of populations. This result is consistent to some extent with recent work by Algan et al. (2019), WHO (2020).

Table 4: Regression result

\begin{tabular}{|c|c|c|}
\hline & \multicolumn{2}{|c|}{ Dependent variable: Happiness } \\
\hline & $(1)$ & $(2)$ \\
\hline Constant & $\begin{array}{l}2.0660 \\
(1.365)\end{array}$ & $\begin{array}{l}1.5260 \\
(1.504)\end{array}$ \\
\hline Covid_Dead & $\begin{array}{c}-0.5382 * * * \\
(0.0516)\end{array}$ & - \\
\hline Covid_Cases & & $\begin{array}{c}-0.0851 * * \\
(0.0336)\end{array}$ \\
\hline Budget_Deficit & $\begin{array}{c}-0.1630^{*} \\
(0.0797)\end{array}$ & $\begin{array}{c}-0.316^{* * * *} \\
(0.109)\end{array}$ \\
\hline Covid_Dead*Budget_Def & $\begin{array}{l}0.0177 * * \\
(0.00811)\end{array}$ & - \\
\hline Covid_Cases*Budget_Def & - & $\begin{array}{c}0.0248 * * * \\
(0.00767)\end{array}$ \\
\hline GDP_Growth & $\begin{array}{c}1.2690 * * * \\
(0.169)\end{array}$ & $\begin{array}{c}1.2390 * * \\
(0.228)\end{array}$ \\
\hline Tourism & $\begin{array}{l}0.0793 * \\
(0.0456)\end{array}$ & $\begin{array}{c}0.0724 \\
(0.0481)\end{array}$ \\
\hline Education & $\begin{array}{l}0.0132 * * \\
(0.00272)\end{array}$ & $\begin{array}{l}0.0140 * * \\
(0.00332)\end{array}$ \\
\hline Capital_Stock & $\begin{array}{c}0.0621 * * * * \\
(0.0212)\end{array}$ & $\begin{array}{c}0.0600 * * * \\
(0.0199)\end{array}$ \\
\hline Duration & $\begin{array}{c}-0.0543 * * \\
(0.02219)\end{array}$ & $\begin{array}{c}-0.0472 * * \\
(0.0231)\end{array}$ \\
\hline Observations & 31 & 31 \\
\hline R-Squared & 0.9974 & 0.9898 \\
\hline Adjusted R-Squared & 0.98541 & 0.9793 \\
\hline
\end{tabular}


Notes: Significance codes are ${ }^{*}, * *$, and $* * *, 10 \%, 5 \%$ and $1 \%$ statistical significance, respectively. Bootstrap standard errors are reported in parenthesis. Fisher probability reports the test statistic of global significance of all variables in the model. Because it value is less than $1 \%$, all the model is globally significant at $1 \%$ threshold.

In the same vein, the touristic activity is highly valued and practiced by the European populations. To this effect, our results prove that the decrease of the said activity and the inaccessibility to the leisure center significantly handicaps the happiness of individuals. In fact, the results show that a $1 \%$ increase in tourism boosts individual satisfaction by $1.19 \%$. These results are consistent with those of Fang et al. (2020). Also, the GDP growth rate has a positive and significant impact in our specification (see column 1). This factor improves material conditions, subsidizes effective containment or containment measures, such as social distancing, and the improvement of related public goods as specified in the study by Condliffe and Link (2008). Higher GDP growth rates are associated with significantly higher levels of happiness. The estimation of column (2) shows that our results are robust when using the active COVID-19. However, using this variable provides us with results close to those obtained in column (1). These results should be taken with much caution as there is unobserved heterogeneity in Europe such as pre-existing immunity for some individuals (Guerrini and Oshadiya, 2020).

\subsection{Taking into account endogeneity}

The analysis of the macroeconomic effects of Covid-19 on happiness and his interaction with budget deficit requires taking into account the phenomenon of endogeneity. The estimation by 2 SLS thus makes it possible to overcome the said problem. At this fact, we consider the budget deficit as the instrument variable.

Table 5: Effect of Covid-19 on happiness: 2SLS approach

\begin{tabular}{lcc}
\hline & \multicolumn{2}{c}{ Dependent variable: Happiness } \\
\cline { 2 - 3 } & $(1)$ & $(2)$ \\
\hline Constant & 1.4681 & 1.2570 \\
& $(1.095)$ & $(1.4421)$ \\
Covid_Dead & $-0.0584^{* * *}$ & - \\
Covid_Cases & $(0.0120)$ & $-0.0510^{* * *}$ \\
& & $(0.0112)$ \\
Budget_Deficit & $-0.297^{* *}$ & $-0.461 * * *$ \\
& $(0.140)$ & $(0.156)$ \\
Covid_Dead*Budget_Def & $0.0314^{* *}$ & - \\
& $(0.0145)$ & \\
Covid_Cases*Budget_Def & - & $0.0356^{* * *}$ \\
& & $(0.0116)$ \\
GDP_Growth & $0.0110^{* * *}$ & $0.0116^{* * *}$ \\
Tourism & $(0.0033)$ & $(0.0039)$ \\
& $0.0940^{*}$ & $0.0909^{*}$ \\
Education & $(0.0488)$ & $(0.0510)$ \\
Capital_Stock & $1.096^{* * *}$ & $1.071 * * *$ \\
& $(0.225)$ & $(0.264)$ \\
& $0.0747^{* * *}$ & $0.0679^{* * *}$ \\
& $(0.0233)$ & $(0.0207)$
\end{tabular}


Observations

Fisher probability reports the test statistic of global significance of all variables in the model. Because it value is less than $1 \%$, all the model is globally significant at $1 \%$ threshold.

In the table 5 above, the Hansen statistic in all estimations exceed 5\%, therefore the validity of the instruments is confirmed for all the specifications used, because the value of the chi-square statistic is not significant in any regression at the required threshold of 5\%.

\section{Conclusion}

The objective of this paper was to assess the impact of COVID-19 and its interaction with the budget deficit on the happiness of European countries. It was discovered, using Generalized Least Squares (GLS) estimation, that death tolls and the worsening of the budget deficit since the outbreak of the COVID-19 epidemic are relevant variables handicapping the life satisfaction of individuals. This result is also confirmed when testing robustness of estimation by considering the number of COVID-19 patients as the variable of interest. These results help to understand the adoption of mobility restrictions that is more restrictive in Europe than elsewhere. However, the number of active cases in Europe decreases with the duration of the pandemic, which shows the adoption of preventive and therapeutic medical measures linked to the subsidies of the governments of the European states. This allows to better control this pandemic. However, the situation is the reverse in Sub-Saharan African countries as the pandemic evolves into insufficient medical materials and preventive methods certified by the World Health Organisations (WHO) (Nguinkeu and Tadadjieu, 2020). Thus, the integration of funds for endemic or pandemic crisis management, mitigation and containment measures adapted to the situation in the state budget could help states. In addition, the creation and construction of new leisure centers respecting distancing measures could reduce the effects of stress and improve mental health to restore the happiness of individuals.

The most obvious limitation of this analysis is insufficient data to assess the impact of restrictive measures (e.g., containment) taken by states on the happiness of populations. The limitations associated with the quality of the indicators used to measure happiness considered as a subjective variable as well as the reporting errors that arise from our results. In the level of the overall European population, it is clear that everyone's mental health has been affected in some way, whether as a result of the worry about becoming infected, or the stress brought about by measures such as self-isolation, lockdown and quarantine, or linked with foregone employment, income, education or social participation. In addition, the econometric approach used may not or fully identify some relevant components of the relationship, especially if measurement errors are correlated with explanatory factors. Another important limitation is the inability of the model to measure the endogenous behavioral responses of some key explanatory variables. 


\section{References}

Algan, Y., E. Beasley, F. Guyot, K. Higa, F. Murtin, and C. Senik (2016). Big data measures of well-being. OECD 1(1), 1-10. https://doi.org/https://doi.org/10.1787/5jlz9hpg0rd1-en.

Algan, Y., Murtin, F., Beasley, E., Higa, K. \& Senik, C. (2019). Well-being through the lens of the internet. PLoS ONE 14(1): e0209562.

Asaoka, H.and Koido, Y., Y. Kawashima, M. Ikeda, Y. Miyamoto, and D. Nishi (2020). Posttraumatic stress symptoms among medical rescue workers exposed to covid-19 in japan. Psychiatry and Clinical Neurosciences 74, 503-505.

Baldwin, R. and Weder di Mauro B. (2020). Economics in the Time of Covid-19. CEPR Press.

Bandyopadhyay, Siddhartha, Chatterjee, Kalyan, Das, Kaustav, Roy, Jaideep, (2021). Learning versus habit formation: optimal timing of lockdown for disease containment. J. Math. Econom. 102452. http://dx.doi.org/10.1016/j.jmateco. 2020.11.008, (in this issue).

Baril-Tremblay, D., Marlats, L., Ménager, C., (2021). Self-isolation. J. Math. Econom. 102483. http://dx.doi.org/10.1016/j.jmateco.2021.102483, (in this issue).

Berger, D., Herkenhoff, K., Mongey, S., (2020). An SEIR infectious disease model with testing and conditional quarantine. NBER Paper 26901.

Blustein, D. L., Kenny, M. E., Di Fabio, A., \& Guichard, J. (2019). Expanding the impact of the psychology of working: Engaging psychology in the struggle for decent work and human rights. Journal of Career Assessment, 27(1), 3-28.

Bosi, S., Camacho, C., Desmarchelier, D. (2021). Optimal lockdowns in altruistic economies. J. Math. Econom. 102488. http://dx.doi.org/10.1016/j.jmateco. 2021.102488, (in this issue).

Bouveret, G., Mandel, A. (2021). Prophylaxis of epidemic spreading with transient dynamics. J. Math. Econom. 102486. http://dx.doi.org/10.1016/j.jmateco.2021. 102486, (in this issue).

Brodeur, A., Clark, A. E., Fleche, S. \& Powdthavee, N. (2020). Assessing the impact of the coronavirus lockdown on unhappiness, loneliness, and boredom using Google Trends. arXiv: 2004.12129. Available at https://ui.adsabs.harvard.edu/abs/ 2020 arXiv 200412129B/abstract

Brotherhood, L., Kircher, C., Santos, P., Tertilt, M. (2020). An economic model of the COVID -19 epidemic: The importance of testing and age-specific policies. Working Paper.

Bryson, A., Clark, A. E., Freeman, R. B. \& Green, C. (2016). Share capitalism and worker well-being. Labor Economics, 42:151-158.

Capuano, R., M. Altieri, A. Bisecco, A. d'Ambrosio, R. Docimo, D. Buonanno, F. Matrone, F. Giuliano, Caulkins, J.P., Grass, G., Feichtinger, R.F., Hartle, P.M., Kort, A., Prskawetzh, A., Seidl, D., Wrzaczek, S. (2021). The optimal lockdown intensity for COVID-19. J. Math. Econom. 102489. http://dx.doi.org/10.1016/j.jmateco.2021.102489, (in this issue).

Chopra, A., Devereux, A., Lahiri, M.B. (2020). Pandemics through the lens of occupations. NBER Working Paper 27841.

Clark, A.E. \& Oswald, A.J. (1994). Unhappiness and Unemployment. Economic Journal, 104(424): 648-659.

Condliffe and Link (2008), "The Relationship between Economic Status and Child Health: Evidence from the United States," American Economic Review, 98(4):1605-18. DOI: 10.1257/aer.98.4.1605 
D'Albis, H., Augeraud-Véron, E. (2021). Optimal prevention and elimination ofinfectious diseases. J. Math. Econom. 102487. http://dx.doi.org/10.1016/j. jmateco.2021.102487, (in this issue).

Di Tella, R., MacCulloch, R.J., and Oswald, A.J. (2001). "Preferences over Inflation and Unemployment: Evidence from Surveys of Happiness." American Economic Review, 91, 335341.

Douglas, M. et al. (2020). "Mitigating the wider health effects of covid-19 pandemic response," The BMJ, Vol. 369, http://dx.doi.org/10.1136/bmj.m1557.

European Central Bank (2020). Available online: https: //www.ecb.europa.eu/home/html/ind ex.en.html (accessed on 1 July 2020).

Fang, H., Wang, L. \& Yang, Y. (2020). Human Mobility Restrictions and the Spread of the Novel Coronavirus (2019-nCoV) in China. NBER Working Paper 26906.

Foa, R., S. Gilbert, and M. O. Fabian (2020). Covid-19 and subjective well-being: Separating the effects of lockdowns from the pandemic. https://www.bennettinstitute.cam.ac.uk/media luploads/files/Happiness_under_Lockdown.pdf

Greyling, T., Rossouw, S. \& Adhikari, T. (2020). Happiness-lost: Did Governments make the right decisions to combat Covid-19? GLO Discussion Paper Series No. 556, Global Labor Organization (GLO).

Greyling, Talita \& Rossouw, Stephanie \& Adhikari, Tamanna, (2020). "A tale of three countries: How did Covid-19 lockdown impact happiness?" GLO Discussion Paper Series 584, Global Labor Organization (GLO).

Gualano, M. R., G. Lo Moro, G. Voglino, F. Bert, and R. Siliquini (2020). Effects of covid-19 lockdown on mental health and sleep disturbances in italy. International Journal of Environmental Research and Public Health 17, 1-13.

Guerrini, I., \& Oshadiya, M. (2020). Potential link between anti malaria prophylaxis and the prevention of COVID-19 infection.

Guimaraes, L. (2021). Antibody tests: They are more important than we thought. J. Math. Econom. 102485.http://dx.doi.org/10.1016/j.jmateco.2021.102485, (in this issue).

Hamermesh, D. (2020). Lockdowns, loneliness and life satisfaction. Bonn, Germany. IZA Discussion Paper Series No. 13140.

Haruna, M. and D. Nishi (2020). Perinatal mental health and covid-19 in japan. Psychiatry and Clinical Neurosciences 74, 502-503.

Jena, P.R., Majhi, R., Kalli, S., Managi, R., Majhi, B., 2021. Impact of COVID-19 on GDP of major economies: Application of the artificial neural network forecaster. Econ. Anal. Policy 69, 324-339.http://dx.doi.org/10.1016/j.eap. 2020.12.013.

Johns Hopkins University. (2020). Coronavirus Resource Centre. Available at https://coronavirus.jhu. edu / map.html Accessed on 8 May 2020.

Jones, N., Wojcik S., Sweeting J., and Silver R. (2016). Tweeting negative emotion: An investigation of twitter data in the aftermath of violence on college campuses. Psychological Methods 21(4), 526-541.

Kapoor, S. and Buiter W. (2020), To fight the COVID pandemic, policymakers must move fast and break taboos (blog), VOX CEPR Policy Portal, https://voxeu.org/article/fightcovidpandemic-policymakers-must-move-fast-and-break-taboos 
Krekel, C., Kolbe, J., and Wuestemann, H. (2016). The Greener, The Happier? The Effect of Urban Land Use on Residential Wellbeing. Ecological Economics, 121, 117-127.

Larson, W.D., Sinclair, T.M., (2021). Nowcasting unemployment insurance claims in the time of COVID-19. Int. J. Forecast.http://dx.doi.org/10.1016/j.ijforecast. 2021.01.001(in press).

Leigh-Hunt, N., Bagguley, D., Bash, K., Turner, V., Turnbull, S., Valtorta, N. \& Caan, W. (2017). An overview of systematic reviews on the public health consequences of social isolation and loneliness. Public Health, 152: 157-171.

Lima, C.K.T., de Medeiros Carvalho, P.M., Lima, I.A.S., et al. (2020). The emotional impact of coronavirus 2019-Ncov (New Coronavirus Disease). Psychiat. Res. https://doi.org/10.1016 lj.psychres.2020.112915.

Luechinger, S. (2009). Valuing Air Quality Using the Life Satisfaction Approach. Economic Journal, 119, 482-515.

Marazziti, D., A. Pozza, M. Di Giuseppe, and C. Conversano (2020). The psychosocial impact of covid-19 pandemic in italy: A lesson for mental health prevention in the first severely hit european country. Psychological Trauma: Theory, Research, Practice, and Policy $12,531-533$.

Maugeri, G., P. Castrogiovanni, G. Battaglia, R. Pippi, V. D'Agata, A. Palma, M. Di Rosa, and G. Musumeci (2020). The impact of physical activity on psychological health during covid-19 pandemic in italy. Heliyon 6, 1-8.

Nguimkeu P. and Tadadjeu S. (2020). Why is the number of COVID-19 cases lower than expected in Sub-Saharan Africa? A cross-sectional analysis of the role of demographic and geographic factors, World Development 138 (2021) 105251, 1-8. https://doi.org/10.10 16/j.worlddev.2020.105251

OECD (2020). COVID-19 and Africa: Socio-economic implications and policy responses, OECD Publishing, Paris, http://www.oecd.org/coronavirus/policy-responses/covid-19-andafricasocio-economic-implications-and-policy-responses-96e1b282

OECD. (2020). COVID-19 crisis response in Central Asia.COVID-19-19 Crisis Response in Central Asia, 2020(2), 1-47.

Orgilés, M., A. Morales, E. Delvecchio, C. Mazzeschi, and J. P. Espada (2020). Immediate psychological effects of the covid-19 quarantine in youth from italy and spain. https://doi.org/10.31234/osf.io/5bpfz

Oswald, A.J., and Wu, S. (2010). Objective Confirmation of Subjective Measures of Human Wellbeing: Evidence from the USA. Science, 327, 576-579.

Piekalkiewicz, M. (2017). Why do economists study happiness? Economic and Labour Relations Review 28(3).

Qian, K. and T. Yahara (2020). Mentality and behavior in covid-19 emergency status in japan: Influence of personality, morality and ideology. PLoS ONE 15, 1-16.

Roca, M., C. Vicens and M. Gili (2020). Covid-19 and the future of mental health in primary care, British Medical Journal Publishing Group, http://dx.doi.org/10.1136/bmj.m2520.

Rossi, R., V. Socci, D. Talevi, S. Mensi, C. Niolu, F. Pacitti, A. Di Marco, A. Rossi, A. Siracusano, and Di Lorenzo G. (2020). Covid-19 pandemic and lockdown measures impact on mental health among the general population in Italy. Frontiers in Psychiatry 11, 1-6. 
Rossouw, S. and T. Greyling (2020). Big data and happiness. In K. Zimmermann (Ed.), Handbook of Labor, Human Resources and Population Economics, pp. 1-35. Springer.

Sani, G., D. Janiri, M. Di Nicola, L. Janiri, S. Ferretti, and D. Chieffo (2020). Mental health during and after the covid-19 emergency in italy. Psychiatry and Clinical Neurosciences 74, 372 .

Shigemura, J. and M. Kurosawa (2020). Mental health impact of the covid-19 pandemic in japan. Psychological Trauma: Theory, Research, Practice, and Policy 12, 478-479.

Shigemura, J.and Ursano, R. J., J. C. Morganstein, M. Kurosawa, and D. M. Benedek (2020). Public responses to the novel 2019 coronavirus (2019-ncov) in japan: Mental health consequences and target populations. Psychiatry and Clinical Neurosciences 74, 281-282.

Sibley, C. G., Greaves, L., Satherley, N., Wilson, M., Lee, C., Milojev, P., Bulbulia, J., Osborne, D., Milfont, T., Overall, N., Houkamau, C. A., Duck, I. M., Vickers-Jones, R. \& Barlow, F. (2020). Short-term Effects of the Covid-19 Pandemic and a Nationwide Lockdown on Institutional Trust, Attitudes to Government, Health and Wellbeing. American Psychological Association. https://psyarxiv.com/cx6qa

Tedeschi G., Santangelo G., and Gallo A. (2020). Psychological consequences of covid-19 pandemic in italianms patients: signs of resilience? Journal of Neurology July(28), 1-8. https://www.ncbi.nlm.nih.gov/pmc/articles/PMC7385478

Torjesen, I. (2020). "Covid-19: Mental health services must be boosted to deal with "tsunami" of cases after lockdown," BMJ (Clinical research ed.), Vol. 369, pp. m1994, http://dx.doi.org/10.1136/bmj.m1994.

Torricelli, L., Poletti, M. and A. Raballo (2020). Managing covid-19 related psychological distress in health workers: field experience in northern italy. Psychiatry and Clinical Neurosciences October (2020), 1-2. https://doi.org/10.1111/pcn.13165

Ueda, M., A. Stickley, H. Sueki, and T. Matsubayashi (2020). Mental health status of the general population in japan during the covid-19 pandemic. Psychiatry and Clinical Neurosciences 74, 505-506.

Van der Wielen, W. and S. Barrios (forthcoming). Economic sentiment during the covid pandemic: Evidence from search behaviour in the eu. Journal of Economics and Business 1, 1-10. http://www.science direct.com/science/article/pii/S0148619520304148.

Verne, P. (2009). Happiness, freedom and control. Journal of Economic Behavior \& Organization, 71(2): 146-161.

World Bank Database. Available online: https: //data.worldbank.org/ (accessed on 1 July 2020).

Yamamoto, T., C. Uchiumi, N. Suzuki, J. Yoshimoto, and E. Murillo-Rodriguez (2020). The psychological impact of 'mild lockdown'in japan during the covid-19 pandemic: a nationwide survey under a declared state of emergency. medRxiv 1(1), 1-24. https://www.medrxiv.org/content /medrxiv/early/2020/07/30/2020.07.17.20156125.full.pdf.

$\underline{\text { Appendix }}$

Table 1: List of countries in the sample 
Belgium, Bulgaria, Czechia, Danmark, Germany, Estonia, Ireland, Greece, Spain, France, Crotia, Italy, Cyprus, Latvia, Lithuania, Luxembourg, Hungary, Malta, Netherlands, Austria, Poland, Portugal, Romania, Slovenia, Slovakia, Finland, Sweden, United Kingdom, Iceland, Norway, switzerland 